\title{
MECHANICAL PROPERTIES OF FIBRE/ FILLER BASED POLY(LACTIC ACID) (PLA) COMPOSITES : A BRIEF REVIEW
}

\author{
Sandip Kumar Mishra \\ Research Scholar, School of Engineering \& Technology, University of Technology \\ Jaipur, Rajasthan, India \\ Sanjeev Dahiya \\ School of Engineering \& Technology, University of Technology \\ Jaipur, Rajasthan, India \\ Brijesh Gangil \\ Mechanical Engineering Department, SOET, HNB Garhwal University \\ Srinagar, Uttarakhand, India, brijeshgangil@gmail.com \\ https://orcid.org/0000-0002-5849-5881 \\ Lalit Ranakoti \\ Department of Mechanical Engineering, NIT \\ Uttarakhand, Srinagar, India \\ Nikita Agrawal \\ Department of Pedodontics, People College of Dental Sciences, \\ Bhopal, MP, India
}

Article history: Received 25 August 2021, Received in revised form 21 September 2021, Accepted 22 September 2021, Available online 2 September 2021

\begin{abstract}
Being a biodegradable polymer, poly(lactic acid) (PLA) based composites receive greater preference over nonbiodegradable plastics. Poly(lactic acid) has to find its place in various applications such as polymer composites, agriculture, biomedical, etc. Polymer composites based on PLA possess comparable mechanical strength, endurance, flexibility and endures future opportunities. Several combinations of natural fibers and filler-based PLA composites have been fabricated and investigated for physical and mechanical changes. Moreover, several biopolymers and compatibilizers are added to PLA to provide rigidity. The paper presents a tabulated review of the various natural fiber/filter-based PLA composites and the preparation and outcomes. In addition, enhancement made by the reinforcement of nano filler in the PLA are also discussed in brief. The significance of PLA in the biomedical application has been discussed in brief. The paper also shed lights in the social and economic aspects of PLA.
\end{abstract}

\section{Keywords}

poly(lactic acid) (PLA); biodegradable composites; mechanical properties.

\section{Introduction}

The increase in carbon emission and the excess usage of plastic polluting the air, land, and water are the major causes for the substitution of plastic for biodegradable polymers [1-3]. In fact, biodegradable polymers have become necessary to maintain an ecological balance between the source and waste production, ensuring minimum waste accumulation in the environment [4-6]. Millions of plastic commodities are being manufactured in everyday life, and almost equal is disposed of in the environment. These plastics are reinforced with various types of fibers and fillers to improve mechanical strength [7-9]. The most typical kinds of plastics used in daily practice are polypropylene, polyethylene, polystyrene, polyvinyl chloride, and polyurethane. The polymers mentioned above take a very long time to degrade hence called plastics or non-biodegradable polymers, due to the presence of a long polymeric chain and shows detrimental effects to the fertility of soil when dumped [10]. In an intention to resolve the issue of biodegradability, various natural and synthetic biopolymers were introduced in the market. Among them, PLA, a synthetic biopolymer, was found suitable to substitute the existing polymers due to good compatibility with other biopolymers to form blends, comparable tensile and flexural strength, large deformation, and remains thermally stable at elevated temperature [11]. PLA can be easily 
manufactured by the process of fermentation and consume less energy during processing. It is cheap and available on the market. The alarming situation of $\mathrm{CO}_{2}$ emission by the use of non-biodegradable polymers can be curbed down by using PLA. Problem of disposing plastic in the landfills and aquatic can also be controlled to some extent. Using PLA as a bio material is not only beneficial economically but also favaourable for environment and social ecosystem.

Many biopolymers are used in biocomposites with projected applications in sectors like automobile, marine engineering, aerospace, electronics, and household ware [12]. In the last decade or two, poly(lactic acid) has been extensively used as a matrix material for the fabrication of bio-composites with several types of reinforcements such as fiber (natural or synthetic), fillers (bio filler or nanofiller), metallic, and ceramics [13]. The properties of PLA-based composite fabricated in the past differ in method of fabrication, weightage of reinforcement, addition of compatibilizers etc. which will be discussed in the literature section.

\section{Process of manufacturing PLA based composites}

Composites based on PLA are prepared by various processes depending upon the nature of reinforcement and type of composite to be prepared. For instance, if the reinforcement is filler type, then twin-screw extruder (Figure 1) and injection moulding is used [14]. Various natural fillers such as wood flour, silicates, carbonates are reinforced in this process. In the case of fiber mat, a compression moulding machine is employed. Several kinds of natural and synthetic fiber can be reinforced with PLA in compression moulding machines such as hemp, kenaf, sisal, coir, wood, carbon, etc. [15-17]. Both the processes are equipped with the provision of a heating element to melt the pallets of PLA. Usually, the temperature range of heating elements is kept between 170$185^{\circ} \mathrm{C}$. Blends of PLA have been often prepared to provide rigidity in which various kinds of biopolymers are added like polyethylene glycol (PEG), poly(butylene succinate) (PBS), poly(hydroxy acid) (PHA), natural rubber (NR), polycaprolactone (PCL) and poly(hydroxy butyrate) (PHB). These blends are prepared by a melt blending process in which polymers are mixed in a beaker and stirred [18]. Thereafter, the required reinforcement is added to the blend. Injection moulding or melt screw moulding is advantageous in several ways over other manufacturing processes like compression moulding, hand lay-up, vacuum assisted resin transfer moulding etc. for example low running cost, specimen for specific dimension can be made directly by using die at the exit, complex material can be fabricated easily, variety of polymer can be easily processed due to the presence of heating element, higher rate of production, longer working life because of low applied pressure and cleanliness of fabricated material due to lower possibility of contamination.

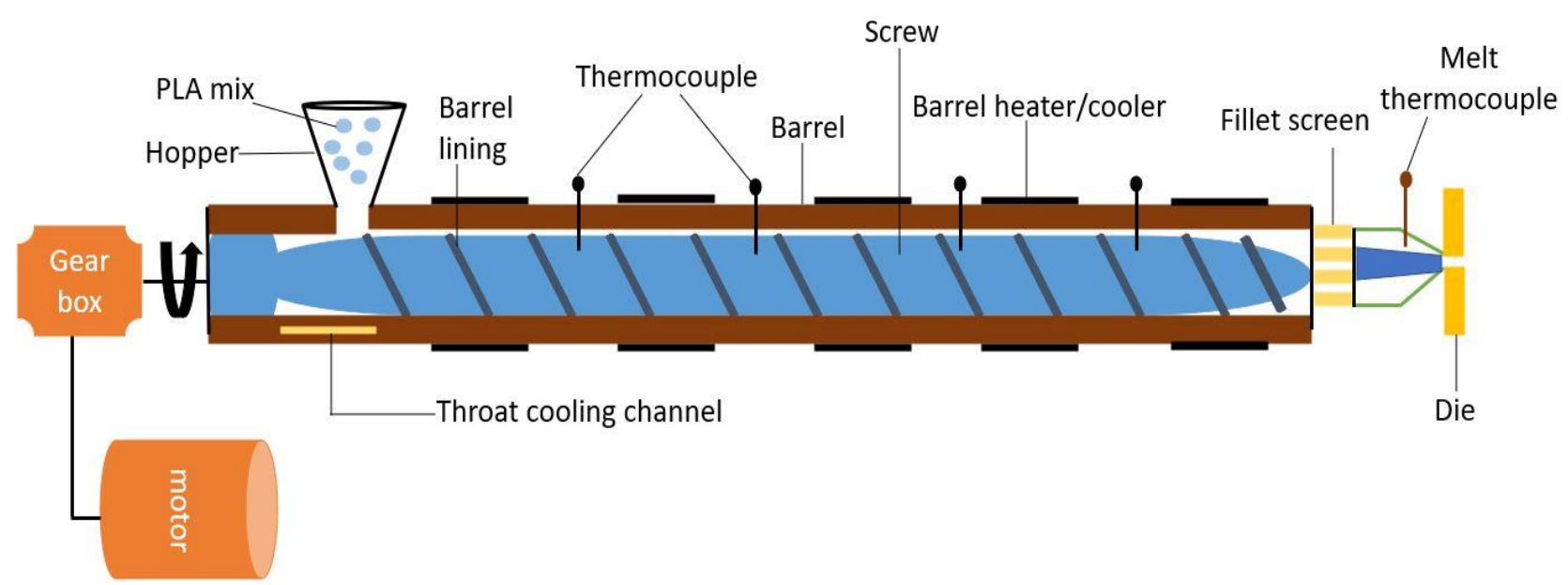

Figure 1. Melt extruder for the fabrication of composite based on PLA [14]. 
Work done on Poly(lactic acid) based composites:

Table.1. PLA based biopolymer reinforced with natural fibre.

\begin{tabular}{|c|c|c|c|c|}
\hline S. No. & Material & Process parameters & Particulars of research & Ref. \\
\hline 1 & $\begin{array}{l}\text { PLA grafted with } 3 \% \\
\text { Maleic anhydride } \\
\text { reinforced with } \\
30 \% \text { and } 50 \% \\
\text { Wood flour }\end{array}$ & $\begin{array}{l}\text { Twin-screw corotating } \\
\text { extruder followed by } \\
\text { injection moulding. }\end{array}$ & $\begin{array}{l}\text { Reduced flexural modulus, storage } \\
\text { modulus, and tensile modulus were } \\
\text { observed whereas failure strain, coefficient } \\
\text { of thermal expansion, and melt flow index } \\
\text { improved. Thermal stability was enhanced } \\
\text { while the crystallinity of PLA decreased. }\end{array}$ & [19] \\
\hline 2 & $\begin{array}{l}\text { PLA with } 5 \% \text { to } 20 \% \\
\text { fleece fiber and coir } \\
\text { fiber }\end{array}$ & $\begin{array}{l}\text { Hot-press moulding at } \\
\text { a temperature of } 170^{\circ} \\
\mathrm{C} \text {, the pressure of } \\
10 \mathrm{MPa} \text {, and moulding } \\
\text { time of } 10 \text { minutes. }\end{array}$ & $\begin{array}{l}\text { An increase in tensile strength of the } \\
\text { composite was observed with an increase } \\
\text { in the percentage of fleece fiber but it } \\
\text { decreases as the fleece fiber weightage } \\
\text { increases to } 20 \% \text {. Modulus of elasticity } \\
\text { increases with an increase in the } \\
\text { percentage of fleece fiber. }\end{array}$ & [20] \\
\hline 3 & $\begin{array}{l}\text { PHB and PLA with } 30 \\
\% \text { short and long } \\
\text { pulp fiber. }\end{array}$ & $\begin{array}{l}\text { Fibers were mixed with } \\
\text { a blend of PHB and PLA } \\
\text { in a torque rheometer } \\
\text { at } 190 \circ \mathrm{C}\end{array}$ & $\begin{array}{l}\text { The impact strength was enhanced by } \\
\text { a factor of } 1.3 \text {, while tensile strength was } \\
\text { enhanced by a factor of } 1.5 \text { as compared to } \\
\text { the virgin blend of PLA and PHB. }\end{array}$ & [21] \\
\hline 4 & $\begin{array}{l}\text { PLA with olive husk } \\
\text { flour at } 10,20 \text {, and } \\
30 \% \text { reinforcement }\end{array}$ & $\begin{array}{l}\text { Composites were } \\
\text { prepared with the } \\
\text { extrusion-injection } \\
\text { moulding method. }\end{array}$ & $\begin{array}{l}\text { Young modulus increased by almost } 27 \% \\
\text { from the initial value with the addition } \\
\text { of olive husk flour. However, the tensile } \\
\text { strength and elongation at break were } \\
\text { reduced owing to poor dispersion and weak } \\
\text { interfacial bonding. Treatment of olive husk } \\
\text { flour resulted in an enhancement } \\
\text { in interfacial bonding and improved } \\
\text { mechanical and thermal properties. }\end{array}$ & [22] \\
\hline 5 & $\begin{array}{l}\text { PLA and short kenaf } \\
\text { fiber }\end{array}$ & $\begin{array}{l}\text { Blend of PLA, and short } \\
\text { kenaf fiber was } \\
\text { prepared by melt } \\
\text { blending in Brabender } \\
\text { internal mixer at } 60 \text { rpm } \\
\text { and } 170^{\circ} \mathrm{C} \text { for } 10 \\
\text { minutes. }\end{array}$ & $\begin{array}{l}\text { The addition of short kenaf fiber improved } \\
\text { the tensile strength and tensile modulus of } \\
\text { the composite up to } 30 \mathrm{wt} \text {. \% of the } \\
\text { reinforcement. At } 40 \mathrm{wt} . \% \text { and } 50 \mathrm{wt} \text {. \% of } \\
\text { kenaf fiber reinforcement, the PLA matrix } \\
\text { unable to wet the fiber and resulted in } \\
\text { reduced tensile strength and tensile } \\
\text { modulus. Change in the crystallinity and } \\
\text { porosity of PLA was also observed due to } \\
\text { the reinforcement of short kenaf fiber }\end{array}$ & [23] \\
\hline 6 & $\begin{array}{l}\text { PLA, PBS, PCL, PBAT, } \\
\text { NR, PCL and grass } \\
\text { fiber }\end{array}$ & $\begin{array}{l}\text { Blending of polymer } \\
\text { was carried out in } \\
\text { laboratory and } \\
\text { reinforced with grass } \\
\text { fiber via injection } \\
\text { moulding }\end{array}$ & $\begin{array}{l}\text { Blending of polymer with NR significantly } \\
\text { improved the impact strength. } \\
\text { Improvement in the tensile strength and } \\
\text { tensile modulus with the incorporation of } \\
\text { grass fiber was observed but the impact } \\
\text { strength and elongation at break reduced. }\end{array}$ & [24] \\
\hline
\end{tabular}




\begin{tabular}{|c|c|c|c|c|}
\hline 7 & PLA and Basalt fiber & $\begin{array}{l}\text { Mixture of PLA and } \\
\text { dried basalt fiber were } \\
\text { prepared in twin screw } \\
\text { extruder and then } \\
\text { passes through } \\
\text { injection moulding for } \\
\text { the preparation of } \\
\text { composite samples }\end{array}$ & $\begin{array}{l}\text { The mechanical properties of PLA increased } \\
\text { linearly with the increase in the percentage } \\
\text { of basalt fiber in composite. The highest } \\
\text { improvement in the mechanical properties } \\
\text { were obtained at } 30 \% \text { weightage of basalt } \\
\text { fiber. }\end{array}$ & {$[25]$} \\
\hline 8 & $\begin{array}{l}\text { PLA and continuous } \\
\text { carbon fiber }\end{array}$ & $\begin{array}{ll}\text { Fused } & \text { deposition } \\
\text { modelling } & \end{array}$ & $\begin{array}{l}\text { The carbon fiber reinforced PLA composite } \\
\text { yielded enhanced tensile and flexural } \\
\text { strength. }\end{array}$ & {$[26]$} \\
\hline 9 & $\begin{array}{l}\text { PLA, chitosan and } \\
\text { carbon fiber }\end{array}$ & $\begin{array}{l}\text { Solvent blending and } \\
\text { immersed glow } \\
\text { moulding process }\end{array}$ & $\begin{array}{l}\text { The presence of chitosan in carbon fiber } \\
\text { PLA composite helped bridge the gap } \\
\text { between the fiber and matrix, resulting in } \\
\text { improved shear and bending modulus. The } \\
\text { rate of bio degradation of the composite } \\
\text { accelerated with the addition of chitosan. }\end{array}$ & [27] \\
\hline 10 & PLA and bamboo fiber & $\begin{array}{l}\text { Composites were } \\
\text { prepared in injection } \\
\text { moulding machines }\end{array}$ & $\begin{array}{l}\text { Bamboo fiber lowered the glass transition } \\
\text { temperature, storage modulus and loss } \\
\text { modulus of the PLA. Moreover, the } \\
\text { mechanical properties of PLA significantly } \\
\text { reduced. }\end{array}$ & [28] \\
\hline 11 & $\begin{array}{l}\text { PLA, benzoyl peroxide, } \\
\text { banana fiber and sisal } \\
\text { fiber }\end{array}$ & $\begin{array}{l}\text { Composites were } \\
\text { prepared by twin screw } \\
\text { extrusion followed by } \\
\text { injection moulding } \\
\text { process. }\end{array}$ & $\begin{array}{l}\text { Excellent improvement in the mechanical } \\
\text { properties of PLA especially in tensile and } \\
\text { flexural strength attributed to the } \\
\text { treatment of fibers with benzoyl peroxide. }\end{array}$ & [29] \\
\hline 12 & $\begin{array}{l}\text { PLA, sugar beet pulp } \\
\text { and sorbitol and } \\
\text { glycerol as plasticizer }\end{array}$ & $\begin{array}{l}\text { Composites were } \\
\text { prepared by twin screw } \\
\text { extrusion followed by } \\
\text { injection moulding } \\
\text { process. }\end{array}$ & $\begin{array}{l}\text { Tensile strength reduced by } 25 \% \text { with the } \\
\text { reinforcement of } 30 \% \text { of sugar beet pulp } \\
\text { whereas the elongation at break increases. } \\
\text { Specific mechanical energy of PLA reduced } \\
\text { from } 1400 \mathrm{~J} / \text { gram to } 1000 \mathrm{~J} / \mathrm{gram} \text {. }\end{array}$ & {$[30]$} \\
\hline 13 & PLA and okra fiber & $\begin{array}{l}\text { Co-rotating twin screw } \\
\text { micro extruder }\end{array}$ & $\begin{array}{l}\text { The stiffness of PLA increased with the } \\
\text { addition of okra fiber. The morphological } \\
\text { study revealed that fiber diameter was } \\
\text { reduced by the chemical treatment but the } \\
\text { interlocking enhanced between the fiber } \\
\text { and matrix. }\end{array}$ & [31] \\
\hline 14 & PLA and chitin & $\begin{array}{l}\text { Melt blending was used } \\
\text { to prepare the blend of } \\
\text { PLA and chitin }\end{array}$ & $\begin{array}{l}\text { The drop in peak degradation temperature } \\
\text { of PLA was observed with the addition } \\
\text { of chitin. Char formation increased as PLA } \\
\text { became more hydrophobic leading to } \\
\text { enhancement in tensile and flexural } \\
\text { strength. }\end{array}$ & {$[32]$} \\
\hline 15 & $\begin{array}{l}\text { PLA, carbon fiber and } \\
\text { SEBS-g-MA as } \\
\text { compatibilizer }\end{array}$ & $\begin{array}{l}\text { Composites samples } \\
\text { were prepared by single } \\
\text { screw extruder }\end{array}$ & $\begin{array}{l}\text { Tensile strength, tensile modulus and } \\
\text { flexural modulus decreased whereas } \\
\text { flexural strength increased marginally and } \\
\text { significant improvement was observed in } \\
\text { the impact strength of PLA with the } \\
\text { addition of chitin. }\end{array}$ & [33] \\
\hline
\end{tabular}




\begin{tabular}{|c|c|c|c|c|}
\hline 16 & $\begin{array}{l}\text { PLA, cassava flour, } \\
\text { pine apple flour and } \\
\text { ash. }\end{array}$ & $\begin{array}{l}\text { Samples were prepared } \\
\text { by injection moulding } \\
\text { machine }\end{array}$ & $\begin{array}{l}\text { Mechanical properties of PLA enhanced up } \\
\text { to } 30 \% \text { of both cassava and pine flour } \\
\text { reinforcement but started decreasing when } \\
\text { the reinforcement weightage increased to } \\
40 \% \text {. }\end{array}$ & [34] \\
\hline 17 & $\begin{array}{l}\text { PLA, basalt fiber and } \\
\text { wood flour }\end{array}$ & $\begin{array}{l}\text { Co rotating twin screw } \\
\text { extruder was used to } \\
\text { fabricated the } \\
\text { composite samples }\end{array}$ & $\begin{array}{l}\text { SEM micro graphs confirm the homogenous } \\
\text { mixing of reinforcements in PLA. There was } \\
\text { no improvement observed in the } \\
\text { mechanical properties of PLA with the } \\
\text { incorporation of basalt fiber rather } \\
\text { decreased with the incorporation of wood } \\
\text { flour in PLA. }\end{array}$ & [35] \\
\hline 18 & $\begin{array}{l}\text { PLA, epoxidized } \\
\text { natural rubber and } \\
\text { lignocellulose fiber }\end{array}$ & $\begin{array}{l}\text { Composites samples } \\
\text { were prepared by using } \\
\text { a vulcanized mould in } \\
\text { press moulding }\end{array}$ & $\begin{array}{l}\text { On mixing natural rubber with PLA, the } \\
\text { elasticity improved. The glass transition } \\
\text { temperature of PLA increased with the } \\
\text { addition of lignocellulose fiber. It was also } \\
\text { found that the decomposition rate of PLA } \\
\text { accelerated due to the incorporation of } \\
\text { silane-treated lignocellulose fiber. }\end{array}$ & [36] \\
\hline 19 & PLA and coir fiber & $\begin{array}{l}\text { Samples were prepared } \\
\text { with co-rotating twin } \\
\text { screw extruder }\end{array}$ & $\begin{array}{l}\text { At } 30 \% \text { reinforcement of coir fiber the } \\
\text { tensile strength reduced to } 52.8 \mathrm{MPa} \text { from } \\
57.4 \text { and elongation of break reduced to } 2 \\
\% \text { from } 3.8 \% \text {. The tensile modulus was } \\
\text { found to be increased from } 4 \mathrm{GPa} \text { to } 4.8 \\
\text { GPa. }\end{array}$ & [37] \\
\hline 20 & PLA and hemp fiber & $\begin{array}{l}\text { Composite samples } \\
\text { were prepared by twin- } \\
\text { screw extrusion and } \\
\text { injection moulding }\end{array}$ & $\begin{array}{l}\text { At } 40 \text { wt. \% loading of hemp fiber in PLA, the } \\
\text { flexural strength, flexural modulus, and } \\
\text { impact strength were found to be } \\
\text { maximum with an increment of } 62 \%, 90 \% \text {, } \\
\text { and } 68 \% \text { respectively as compared to virgin } \\
\text { PLA. }\end{array}$ & [38] \\
\hline 21 & $\begin{array}{l}\text { PLA, } 25 \text { wt. \% cotton } \\
\text { linters and } 50 \text { wt. \% } \\
\text { Mapple fiber }\end{array}$ & $\begin{array}{l}\text { Composites samples } \\
\text { were prepared via } \\
\text { compounding followed } \\
\text { by injection moulding }\end{array}$ & $\begin{array}{l}\text { Marginal increase in the overall density was } \\
\text { achieved with the addition of } 25 \% \text { cotton } \\
\text { linters in the PLA. Flexural modulus of PLA } \\
\text { was increased by } 56 \% \text { and } 123 \% \text { by the } \\
\text { addition of cotton linters and Mapple fiber } \\
\text { respectively. Significant improvement in } \\
\text { the impact strength of PLA was also } \\
\text { observed. }\end{array}$ & [39] \\
\hline 22 & $\begin{array}{l}\text { PLA, office waste } \\
\text { paper and PBAT }\end{array}$ & $\begin{array}{l}\text { Composites were } \\
\text { prepared by melt } \\
\text { blending and injection } \\
\text { moulding }\end{array}$ & $\begin{array}{l}\text { The impact strength of PLA was enhanced } \\
\text { by } 291 \% \text { at } 20 \text { wt. \% of office waste paper } \\
\text { but the flexural modulus and flexural } \\
\text { strength decreased. PBAT addition in PLA } \\
\text { increases the water uptake stepwise. }\end{array}$ & [40] \\
\hline 23 & $\begin{array}{l}\text { PLA, kenaf fiber and } \\
\text { rice husk }\end{array}$ & $\begin{array}{l}\text { Compounding of PLA } \\
\text { with fibers were carried } \\
\text { out followed by } \\
\text { samples preparation by } \\
\text { injection moulding }\end{array}$ & $\begin{array}{l}\text { The flexural modulus of PLA increased } \\
\text { around } 32 \% \text { and } 18 \% \text { with the addition of } \\
\text { kenaf fiber and rice husk respectively. } \\
\text { However, flexural strength and impact } \\
\text { strength decreased. }\end{array}$ & {$[41]$} \\
\hline 24 & $\begin{array}{l}\text { PLA, bamboo fiber and } \\
\text { silane coupling agent }\end{array}$ & $\begin{array}{l}\text { Composite samples } \\
\text { were prepared by } \\
\text { injection moulding }\end{array}$ & $\begin{array}{l}\text { Storage modulus and loss modulus of PLA } \\
\text { decreased as the weight percentage } \\
\text { of bamboo fiber increased in the } \\
\text { composite. }\end{array}$ & [28] \\
\hline
\end{tabular}




\begin{tabular}{|c|c|c|c|c|}
\hline 25 & $\begin{array}{l}\text { PLA, benzylated } \\
\text { treated rice straw and } \\
\text { nano clay }\end{array}$ & $\begin{array}{l}\text { Solvent casting method } \\
\text { was used to prepare the } \\
\text { composite samples }\end{array}$ & $\begin{array}{l}\text { Reduction in the peak intensity of the } \\
\text { cellulosic hydroxyl group was observed with } \\
\text { the addition of treated tice straw due to the } \\
\text { formation of aromatic bonds. A slight } \\
\text { increase in the crystallinity of PLA was } \\
\text { observed due to strong molecular } \\
\text { interaction between fiber and PLA. }\end{array}$ & [42] \\
\hline 26 & PLA and rice straw & $\begin{array}{l}\text { Alkali pulping and } \\
\text { benzylation was } \\
\text { performed on the rice } \\
\text { straw followed by twin } \\
\text { screw extruder for the } \\
\text { composite fabrication }\end{array}$ & $\begin{array}{l}\text { The addition of rice straw in PLA resulted in } \\
\text { the lowering of glass transition } \\
\text { temperature and melting temperature. } \\
\text { Early degradation of the composite was } \\
\text { confirmed by the SEM micrographs. }\end{array}$ & [43] \\
\hline 27 & $\begin{array}{l}\text { PLA and thin strip of } \\
\text { bamboo }\end{array}$ & $\begin{array}{l}\text { Strips of bamboo were } \\
\text { bonded in PLA with the } \\
\text { help of compression } \\
\text { moulding machine for } \\
\text { the fabrication of } \\
\text { composites }\end{array}$ & $\begin{array}{l}\text { Excellent enhancement in the mechanical } \\
\text { properties of PLA was obtained due to the } \\
\text { influence of the node. Highly stiffed } \\
\text { composite can be fabricated via } \\
\text { compression moulding process. }\end{array}$ & [44] \\
\hline 28 & PLA and 10 wt. \% PEG & $\begin{array}{l}\text { Melt blending and co } \\
\text { rotating twin screw } \\
\text { extruder }\end{array}$ & $\begin{array}{l}\text { PEG plasticized the PLA but the mechanical } \\
\text { properties were reduced. }\end{array}$ & {$[45]$} \\
\hline 29 & $\begin{array}{l}\text { PLA, raw fiber } \\
\text { obtained from acid- } \\
\text { catalysed hydrolysis } \\
\text { and delignified fiber }\end{array}$ & $\begin{array}{l}\text { Samples were prepared } \\
\text { by co rotating twin } \\
\text { extruder }\end{array}$ & $\begin{array}{l}\text { Marginal improvement was observed in the } \\
\text { tensile strength of PLA with the addition of } \\
\text { raw fiber. Formation of pores and voids } \\
\text { took place due to the addition of oat } \\
\text { delignified fiber. }\end{array}$ & {$[46]$} \\
\hline 30 & $\begin{array}{l}\text { PLA and nanometric } \\
\text { and micrometric } \\
\text { cellulose filler }\end{array}$ & $\begin{array}{l}\text { Solvent casting method } \\
\text { was used for the } \\
\text { fabrication of blend }\end{array}$ & $\begin{array}{l}\text { Higher young modulus and tensile strength } \\
\text { were obtained for nanometric filled PLA } \\
\text { composite as compared to micrometric } \\
\text { filled PLA composite }\end{array}$ & {$[47]$} \\
\hline 31 & $\begin{array}{l}\text { PLA, starch, cellulose } \\
\text { fiber in powder form } \\
\text { and carnauba wax, }\end{array}$ & $\begin{array}{l}\text { Foam composite was } \\
\text { prepared by } \\
\text { compression moulding }\end{array}$ & $\begin{array}{l}\text { The foam containing } 9 \% \text { PLA showed the } \\
\text { highest improvement in tensile strength } \\
\text { with an increment of } 31 \% \text { as compared to } \\
\text { foam without PLA. }\end{array}$ & {$[48]$} \\
\hline 32 & $\begin{array}{l}\text { PLA with } 10 \% \text { copper } \\
\text { fibers }\end{array}$ & $\begin{array}{l}\text { Compression moulding } \\
\text { technique }\end{array}$ & $\begin{array}{l}\text { Viscoelastic behaviour of PLA enhanced } \\
\text { with the addition of copper fiber. The PLA } \\
\text { became more thermally stable due to the } \\
\text { reinforcement of copper fibers. }\end{array}$ & [49] \\
\hline
\end{tabular}

The results reported in the tabulated form (Table 1) conclude that reinforcing PLA with fiber/filler reduces the strength but enhances the modulus and stiffness. Various compatibilizers are added in the PLA to improve the mechanical interaction between fiber and PLA and enhances the melting point temperature. The addition of copolymer increases toughness and crystallinity of PLA due to formation of cross linkage. In addition, the dynamic mechanical properties such as loss modulus and storage modulus are also enhanced by the addition of copolymers.

Poly(lactic acid) based nano composite

Various inorganic and organic materials can be incorporated in PLA to enhance its mechanical and thermal properties. These incorporations, when performed at nanoscale then it is called nano composites. 


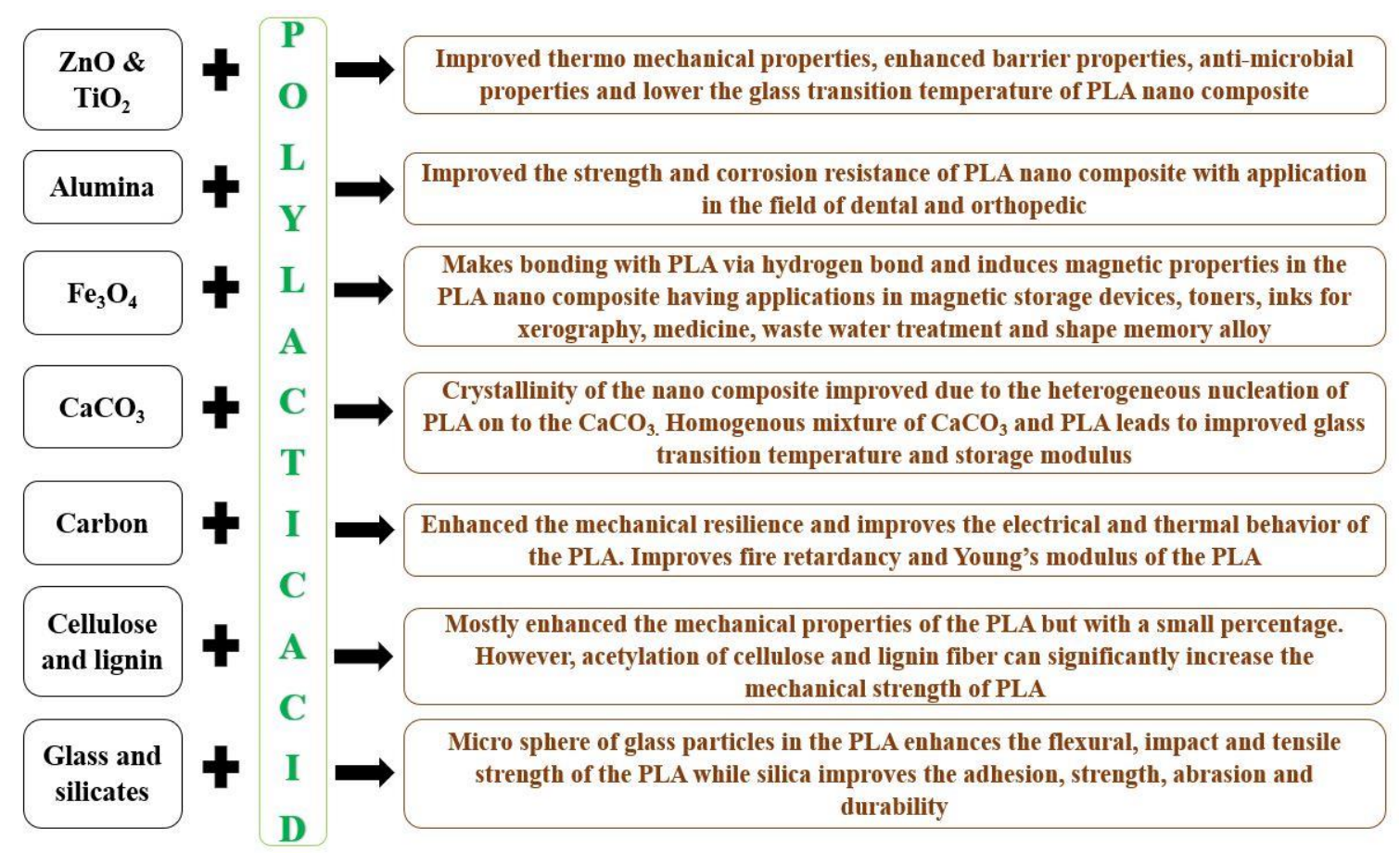

Figure 2. PLA based nano composites [50-70].

A minimal amount of nanofiller is sufficient to improve the mechanical and thermal properties of the PLA significantly. Due to the high surfac to volume ratio of nano filler, it is usually reinforced in a small amount i.e. upto $5 \%$. It generally occupies the vacant position in the matrix and provides rigidity to the composites leading to high impact and tensile strength. Significant enhancement in the strength of PLA has been reported in the past by reinforcing various nano fillers such as $\mathrm{ZnO}$, silicates, $\mathrm{CaCO}_{3}, \mathrm{Fe}_{3} \mathrm{O}_{4}, \mathrm{TiO}_{2}$ etc. nano fillers not only provides strength to PLA but also improves thermal characteristics. Various nano fillers-PLA composite and their properties enhancement is shown in Figure 2.

\section{Application of PLA based composites}

Despite being subjected to various composite manufacturing as a matrix material, poly (lactic acid) has also been used in the field of biomedical. It has favorable characteristics such as biodegradability, biocompatibility, hydrolyzed under environmental conditions, low immunogenicity, etc. that makes it a suitable polymer for various biomedical applications, as illustrated in Figure 3. It is used in orthopedic implants in which biocomposites based on PLA are used for bone fixation and implant for tissue recovery. Blends of PLA, polyglycolide (PGA), and di-oxanone are used for orthognathic surgery, a pretreatment for maxillofacial fractures. PLA blends provide comfort and relief to the implants and eliminate the secondary process of healing [71]. Several drug delivery systems are prepared by PLA. A combination of lactide group and glycolic acid are used for lipophilic drugs, chemotherapeutic drugs, and therapeutic agents. Antigen release can also be accomplished by combining microsphere of chitosan with poly(glycolic acid) [72].

Scaffolds prepared from PLA and collagen are effectively used to stimulate and proliferate cell generation in tissue engineering. The augmentation of soft tissue damage has been successfully achieved by phosphate-PLA biocomposite for bone tissue engineering. Successfully implementing composite based on poly (lactic acid) as an antimicrobial agent has been accomplished forbidding micro-organism growth in water sanitation plant [73]. Research and development are also in progress to develop stents based on PLA used for the clinical problem that arises in the ureteral system. Various electronic controller systems are now being fabricated from poly(lactic acid) leading to mutual compatibility, less space, efficient power, and reliability as compared to conventional material. Teabags, packaging materials, and other household ware are also manufactured with poly(lactic acid). 

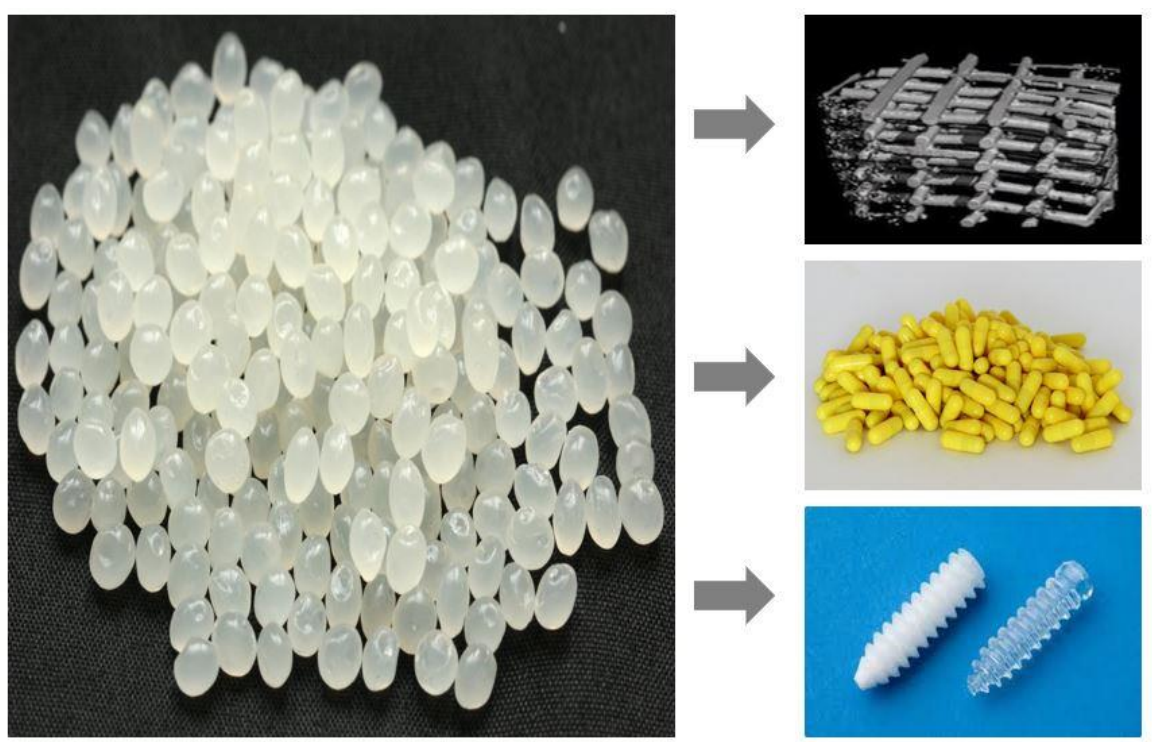

Scaffolding for tissue engineering, cartilage, liver and bone tissue

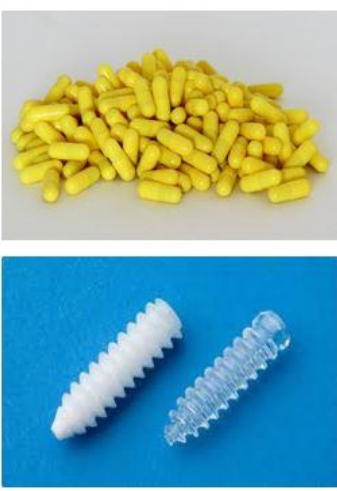

Dosage for pellets, microsphere, targeted drug and peptide protein

Implants (screw, fixation rods and wound cover)

Poly lactic acid pellets

Figure 3. Biomedical scope of poly(lactic acid) [71].

\section{Impact}

Cost of production of any mateiral is the crucial parameter which decides its viability and future sustainability in the industry. Today, various companies like NatureWorks, Futerro, Corbion etc. are providing PLA at reasonable cost. The quality of PLA offer by these companies are worth buying but the original production cost is unknown to almost everyone except few producers. To assess the original production cost of the PLA a number of experiments were performed. Raw material used for the production of PLA were potato starch, wood extract, cassava extract, food waste, triticale and corn. The cost of production incurred in the analysis varied according to the method adopted. The detailed cost analysis of PLA production is explained in Table 2. The variation in the cost is the result of method used in the production, type of feed stock and other direct and indirect cost considered in the investigation therefore a comparison among the studies on the basis of production cost will not be justified. Nevertheless, various methods of producing PLA at different working conditions have evolved through research and technical advancement.

By using different types feedstock and technique, we can lower down the production cost of PLA as shown in Table 2. However, the commercialization of the method will depend on the balance between its cost and environmental effect. PLA is well-known for its low $\mathrm{CO}$ emission and the feedstock i.e. corn, consumes $\mathrm{CO}_{2}$ during its cultivation [74]. Comparing the carbon emission of PLA production with other typical polymers, it was found that PLA has negative green house gas emission [75]. This makes the PLA acts as a green house gas sink and coupling this with latest process technology will definitely leads to the formation of green environment. 
Table 2. Cost analysis of PLA produced by different method [76-79].

\begin{tabular}{|c|c|c|c|}
\hline Feedstock & Technique & Cost incurred & Remark \\
\hline Potato starch & $\begin{array}{l}\text { Bacterial fermentation } \\
\text { (Green field } \\
\text { technology) }\end{array}$ & $\begin{array}{l}\text { Cost of dextrose, waste disposal } \\
\text { cost, revenue cost, fixed cost such } \\
\text { as electricity cost and overhead } \\
\text { cost }\end{array}$ & $\begin{array}{l}\$ 2.9 \text { US production cost } \\
\text { per kg of PLA }\end{array}$ \\
\hline $\begin{array}{l}\text { Sugar extract } \\
\text { from wood }\end{array}$ & $\begin{array}{l}\text { Bacterial fermentation } \\
\text { (Brownfield } \\
\text { technology) }\end{array}$ & $\begin{array}{l}\text { Lowers the capital cost, annual } \\
\text { operating costs, including taxes, } \\
\text { insurance, maintenance, return } \\
\text { on investment and other } \\
\text { expenses }\end{array}$ & $\begin{array}{l}\$ 2.62 \text { US production cost } \\
\text { per kg of PLA }\end{array}$ \\
\hline Corn starch & Yeast fermentation & $\begin{array}{l}\text { Lower the waste cost and process } \\
\text { cost }\end{array}$ & $\begin{array}{l}\$ 2.12 \text { US production cost } \\
\text { per kg of PLA }\end{array}$ \\
\hline Cassava root & Cargill dow process & $\begin{array}{l}\text { Costs of PLA production, raw } \\
\text { material costs (cassava roots and } \\
\text { chemicals), capital costs, labour } \\
\text { costs, operating costs, and waste } \\
\text { treatment costs, environmental } \\
\text { cost and cost of } \mathrm{CO}_{2} \text { emissions } \\
\text { resulting from electricity and fuel } \\
\text { consumption }\end{array}$ & $\begin{array}{l}\$ 2.71 \text { US production cost } \\
\text { per kg of PLA }\end{array}$ \\
\hline Cassava starch & Cargill dow process & $\begin{array}{l}\text { Raw material costs (cassava } \\
\text { starch, capital costs, labour costs, } \\
\text { operating costs, and waste } \\
\text { treatment costs, environmental } \\
\text { cost and cost of } \mathrm{CO}_{2} \text { emissions and } \\
\text { waste cost (gypsum) }\end{array}$ & $\begin{array}{l}\$ 2.82 \text { US production cost } \\
\text { per kg of PLA }\end{array}$ \\
\hline $\begin{array}{ll}\text { Cereal crops } \\
\text { (triticale) }\end{array}$ & Baseline technology & $\begin{array}{l}\text { Costs of raw materials (biomass } \\
\text { and chemicals), energy and } \\
\text { operating materials, maintenance } \\
\text { and repair, labour, operating } \\
\text { materials, insurance and } \\
\text { overhead, administration, } \\
\text { distribution and sales }\end{array}$ & $\begin{array}{l}\$ 1.2 \text { US production cost } \\
\text { per kg of PLA }\end{array}$ \\
\hline Corn grains & Bio refinery & $\begin{array}{l}\text { Equipment cost, raw materials } \\
\text { cost, energy cost, labour cost and } \\
\text { costs of producing lactic acid from } \\
\text { bacteria, fungi and yeast-based } \\
\text { fermentation }\end{array}$ & $\begin{array}{l}\$ 0.84 \text { US production cost } \\
\text { per kg of PLA }\end{array}$ \\
\hline
\end{tabular}

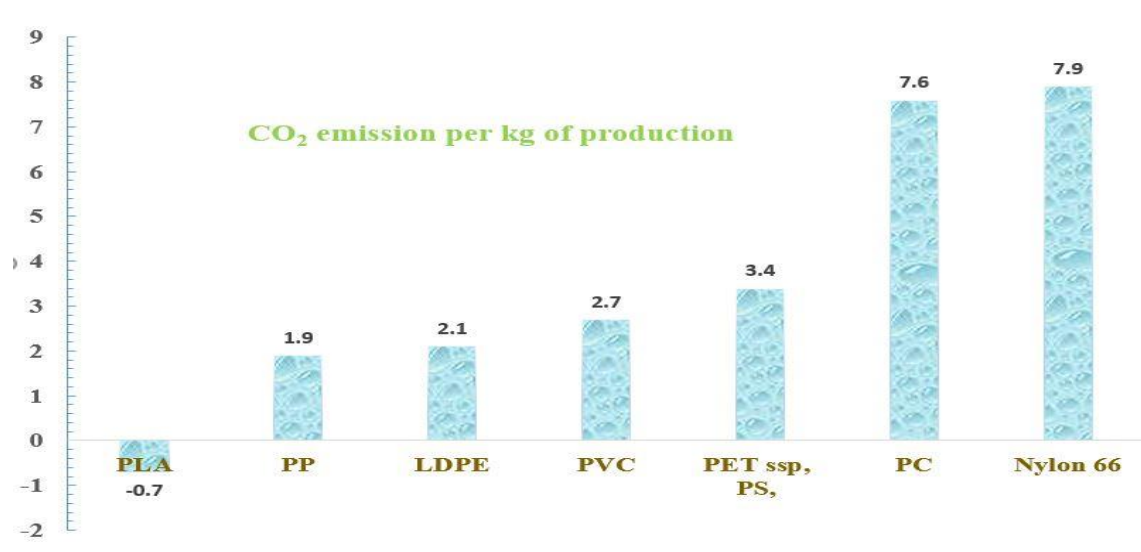

Figure 4. $\mathrm{CO}_{2}$ emission by various polymers [80]. 


\section{Conclusions}

The fabrication of the biocomposites in the coming future will be given preference over non-biodegradable composites due to the strict regulations as specified by the United Nation environmental program (UNEP) for the prevention of the environment from the hazardous effect of the polymer waste where poly(lactic acid) can play a crucial role. Different types of biopolymers compatible with PLA need to be exposed to expand its scope for the fabrication of sustainable material that could perform in real-time conditions.

Poly(lactic acid) is readily available in pallet form and is widely used for the manufacturing of boi-composites particularly via melt extruder and injection moulding. Various favourable changes in mechanical and wear characteristics of PLA have been reported along with some future suggestions. PLA showed decreasing characteristics of tensile and flexural strength with the addition of filler which can be modified with the use of compatibilizers or mixing of suitable biopolymers.

Biodegradable implants are primarily designed from PLA-based composites and are expected to be made from pure PLA in the near future also. The emerging biomedical tailorable applications will be made from the PLA and its copolymer blends such as glycolic acid, caprolactone, and polyethylene glycol.

\section{Conflict of interest}

There are no conflicts to declare.

\section{Acknowledgments}

This research has not been supported by any external funding.

\section{Reference}

[1] M. Shen, B. Song, G. Zeng, Y. Zhang, W. Huang, X. Wen, W. Tang, Are biodegradable plastics a promising solution to solve the global plastic pollution?, Environ. Pollut. 263 (2020) 114469. https://doi.org/10.1016/j.envpol.2020.114469.

[2] S.P. Gairola, Y.K. Tyagi, B. Gangil, A. Sharma, Fabrication and mechanical property evaluation of nonwoven banana fibre epoxy-based polymer composite, in: Mater. Today Proc., 2020: pp. 3990-3996. https://doi.org/10.1016/j.matpr.2020.10.103.

[3] L. Ranakoti, P.K. Rakesh, Physio-mechanical characterization of tasar silk waste/jute fiber hybrid composite, Compos. Commun. 22 (2020) 100526. https://doi.org/10.1016/j.coco.2020.100526.

[4] B. Yadav, A. Pandey, L.R. Kumar, R.D. Tyagi, Bioconversion of waste (water)/residues to bioplasticsA circular bioeconomy approach, Bioresour. Technol. $298 \quad$ (2020) 122584. https://doi.org/10.1016/j.biortech.2019.122584.

[5] S. Rodriguez-Perez, A. Serrano, A.A. Pantión, B. Alonso-Fariñas, Challenges of scaling-up PHA production from waste streams. A review, J. Environ. Manage. 205 (2018) 215-230. https://doi.org/10.1016/j.jenvman.2017.09.083.

[6] S.K. Verma, A. Gupta, T. Singh, B. Gangil, E. Jánosi, G. Fekete, Influence of dolomite on mechanical, physical and erosive wear properties of natural-synthetic fiber reinforced epoxy composites, Mater. Res. Express. 6 (2019) 125704. https://doi.org/10.1088/2053-1591/ab5abb.

[7] R. Siakeng, M. Jawaid, H. Ariffin, S.M. Sapuan, M. Asim, N. Saba, Natural fiber reinforced polylactic acid composites: A review, Polym. Compos. 40 (2019) 446-463. https://doi.org/10.1002/pc.24747.

[8] L. Ranakoti, B. Gangil, P. Kumar Rakesh, N. Agrawal, Synthesis and Utilization of Biodegradable Polymers, in: Biobased Compos., Wiley, 2021: pp. 167-174. https://doi.org/10.1002/9781119641803.ch12.

[9] A. Basu, M. Nazarkovsky, R. Ghadi, W. Khan, A.J. Domb, Poly(lactic acid)-based nanocomposites, Polym. Adv. Technol. 28 (2017) 919-930. https://doi.org/10.1002/pat.3985.

[10] F. Saliu, S. Montano, M.G. Garavaglia, M. Lasagni, D. Seveso, P. Galli, Microplastic and charred microplastic in the Faafu Atoll, Maldives, Mar. Pollut. Bull. 136 (2018) 464-471. https://doi.org/10.1016/j.marpolbul.2018.09.023.

[11] E. Kabir, R. Kaur, J. Lee, K.H. Kim, E.E. Kwon, Prospects of biopolymer technology as an alternative option for non-degradable plastics and sustainable management of plastic wastes, J. Clean. Prod. 258 (2020) 120536. https://doi.org/10.1016/j.jclepro.2020.120536.

[12] T.G. Yashas Gowda, M.R. Sanjay, K. Subrahmanya Bhat, P. Madhu, P. Senthamaraikannan, B. Yogesha, Polymer matrix-natural fiber composites: An overview, Cogent Eng. 5 (2018) 1446667. https://doi.org/10.1080/23311916.2018.1446667.

[13] A. Ilyas Rushdana, M. Sapuan Salit, M. Lamin Sanyang, M. Ridzwan Ishak, Nanocrystalline Cellulose As Reinforcement For Polymeric Matrix Nanocomposites And Its Potential Applications: A Review, Curr. 
Anal. Chem. 13 (2017) 203-225. https://doi.org/10.2174/1573411013666171003155624.

[14] X. Cui, A. Ozaki, T.A. Asoh, H. Uyama, Cellulose modified by citric acid reinforced Poly(lactic acid) resin $\begin{array}{llllll}\text { as fillers, } & \text { Polym. } & \text { Degrad. } & \text { Stab. } & 175 & \text { (2020) }\end{array}$ https://doi.org/10.1016/j.polymdegradstab.2020.109118.

[15] M.K. Lila, K. Shukla, U.K. Komal, I. Singh, Accelerated thermal ageing behaviour of bagasse fibers reinforced Poly (Lactic Acid) based biocomposites, Compos. Part B Eng. 156 (2019) 121-127. https://doi.org/10.1016/j.compositesb.2018.08.068.

[16] J.O. Akindoyo, M.D.H. Beg, S. Ghazali, H.P. Heim, M. Feldmann, M. Mariatti, Simultaneous impact modified and chain extended glass fiber reinforced poly(lactic acid) composites: Mechanical, thermal, crystallization, and dynamic mechanical performance, J. Appl. Polym. Sci. 138 (2021) 49752. https://doi.org/10.1002/app.49752.

[17] G. Wang, D. Zhang, B. Li, G. Wan, G. Zhao, A. Zhang, Strong and thermal-resistance glass fiber-reinforced polylactic acid (PLA) composites enabled by heat treatment, Int. J. Biol. Macromol. 129 (2019) 448-459. https://doi.org/10.1016/j.ijbiomac.2019.02.020.

[18] X. Zuo, Y. Xue, L. Wang, Y. Zhou, Y. Yin, Y.C. Chuang, C.C. Chang, R. Yin, M.H. Rafailovich, Y. Guo, Engineering Styrenic Blends with Poly(lactic acid), Macromolecules. 52 (2019) 7547-7556. https://doi.org/10.1021/acs.macromol.9b01349.

[19] S. Bhattacharjee, D.S. Bajwa, Feasibility of Reprocessing Natural Fiber Filled Poly(lactic acid) Composites: An In-Depth Investigation, Adv. Mater. Sci. Eng. $2017 \quad$ (2017) 1-10. https://doi.org/10.1155/2017/1430892.

[20] L. Musyarofah, D. Puspita, E. Hidayah, Sujito, Tensile properties of coir and fleece fibers reinforced polylactic acid hybrid green composites, in: J. Phys. Conf. Ser., 2019: p. 012008. https://doi.org/10.1088/1742-6596/1217/1/012008.

[21] H. Ren, Y. Zhang, H. Zhai, J. Chen, Production and evaluation of biodegradable composites based on polyhydroxybutyrate and polylactic acid reinforced with short and long pulp fibers, Cellul. Chem. Technol. 49 (2015) 641-652.

[22] T. Yu, J. Ren, S. Li, H. Yuan, Y. Li, Effect of fiber surface-treatments on the properties of poly(lactic acid)/ramie composites, Compos. Part A Appl. Sci. Manuf. 41 (2010) 499-505. https://doi.org/10.1016/j.compositesa.2009.12.006.

[23] N.A. Ibrahim, W. Md Zin Wan Yunus, M. Othman, K. Abdan, K.A. Hadithon, Poly(Lactic Acid) (PLA)reinforced kenaf bast fiber composites: The effect of triacetin, J. Reinf. Plast. Compos. 29 (2010) 10991111. https://doi.org/10.1177/0731684409344651.

[24] P. Juntuek, C. Ruksakulpiwat, P. Chumsamrong, Y. Ruksakulpiwat, Mechanical properties of polylactic acid and natural rubber blends using vetiver grass fiber as filler, in: Adv. Mater. Res., 2010: pp. 11671170. https://doi.org/10.4028/www.scientific.net/AMR.123-125.1167.

[25] T. Tábi, N.K. Kovács, J.G. Kovács, Basalt fibre reinforced poly (LACTIC ACID) based composites for engineering applications, in: 16th Eur. Conf. Compos. Mater. ECCM 2014, 2014.

[26] X. Tian, T. Liu, C. Yang, Q. Wang, D. Li, Interface and performance of 3D printed continuous carbon fiber reinforced PLA composites, Compos. Part A Appl. Sci. Manuf. 88 (2016) 198-205. https://doi.org/10.1016/j.compositesa.2016.05.032.

[27] W. Xu, The mechanical properties of Carbon fiber/Polylatide/Chitosan composites, in: 20104 th Int. Conf. Bioinforma. Biomed. Eng. ICBBE 2010, IEEE, 2010: pp. 1-4. https://doi.org/10.1109/ICBBE.2010.5515711.

[28] X.G. Li, X. Zheng, Y.Q. Wu, DMA analysis on bamboo fiber/polylactic acid composites, in: 2010 Int. Conf. Mech. Autom. Control Eng. MACE2010, IEEE, 2010: pp. 3090-3092. https://doi.org/10.1109/MACE.2010.5535322.

[29] B. Asaithambi, G. Ganesan, S. Ananda Kumar, Bio-composites: Development and mechanical characterization of banana/sisal fibre reinforced poly lactic acid (PLA) hybrid composites, Fibers Polym. 15 (2014) 847-854. https://doi.org/10.1007/s12221-014-0847-y.

[30] V.L. Finkenstadt, C.K. Liu, P.H. Cooke, L.S. Liu, J.L. Willett, Mechanical property characterization of plasticized sugar beet pulp and poly(lactic acid) green composites using acoustic emission and confocal microscopy, J. Polym. Environ. 16 (2008) 19-26. https://doi.org/10.1007/s10924-008-0085-8.

[31] E. Fortunati, D. Puglia, M. Monti, C. Santulli, M. Maniruzzaman, M.L. Foresti, A. Vazquez, J.M. Kenny, Okra (Abelmoschus esculentus) Fibre Based PLA Composites: Mechanical Behaviour and Biodegradation, J. Polym. Environ. 21 (2013) 726-737. https://doi.org/10.1007/s10924-013-0571-5.

[32] M.M. Hassan, K. Koyama, Thermomechanical and viscoelastic properties of green composites of PLA using chitin micro-particles as fillers, J. Polym. Res. 27 (2020) 27. https://doi.org/10.1007/s10965-019- 
1991-2.

[33] C.T. Hsieh, Y.J. Pan, C.W. Lou, C.L. Huang, Z.I. Lin, J.M. Liao, J.H. Lin, Polylactic acid/carbon fiber composites: Effects of functionalized elastomers on mechanical properties, thermal behavior, surface compatibility, and electrical characteristics, Fibers Polym. 17 (2016) 615-623. https://doi.org/10.1007/s12221-016-5922-0.

[34] K.W. Kim, B.H. Lee, H.J. Kim, K. Sriroth, J.R. Dorgan, Thermal and mechanical properties of cassava and pineapple flours-filled PLA bio-composites, in: J. Therm. Anal. Calorim., 2012: pp. 1131-1139. https://doi.org/10.1007/s10973-011-1350-y.

[35] S. Kuciel, K. Mazur, M. Hebda, The Influence of Wood and Basalt Fibres on Mechanical, Thermal and Hydrothermal Properties of PLA Composites, J. Polym. Environ. 28 (2020) 1204-1215. https://doi.org/10.1007/s10924-020-01677-z.

[36] A. Masek, K. Diakowska, M. Zaborski, Physico-mechanical and thermal properties of epoxidized natural rubber/polylactide (ENR/PLA) composites reinforced with lignocellulose, J. Therm. Anal. Calorim. 125 (2016) 1467-1476. https://doi.org/10.1007/s10973-016-5682-5.

[37] T.R. Rigolin, M.C. Takahashi, D.L. Kondo, S.H.P. Bettini, Compatibilizer Acidity in Coir-Reinforced PLA Composites: Matrix Degradation and Composite Properties, J. Polym. Environ. 27 (2019) 1096-1104. https://doi.org/10.1007/s10924-019-01411-4.

[38] Y. Song, J. Liu, S. Chen, Y. Zheng, S. Ruan, Y. Bin, Mechanical Properties of Poly (Lactic Acid)/Hemp Fiber Composites Prepared with a Novel Method, J. Polym. Environ. 21 (2013) 1117-1127. https://doi.org/10.1007/s10924-013-0569-z.

[39] C. Way, D.Y. Wu, D. Cram, K. Dean, E. Palombo, Processing Stability and Biodegradation of Polylactic Acid (PLA) Composites Reinforced with Cotton Linters or Maple Hardwood Fibres, J. Polym. Environ. 21 (2013) 54-70. https://doi.org/10.1007/s10924-012-0462-1.

[40] C. Xu, X. Zhang, X. Jin, S. Nie, R. Yang, Study on Mechanical and Thermal Properties of Poly(Lactic acid)/Poly(Butylene adipate-co-terephthalate)/Office Wastepaper Fiber Biodegradable Composites, J. Polym. Environ. 27 (2019) 1273-1284. https://doi.org/10.1007/s10924-019-01428-9.

[41] A.A. Yussuf, I. Massoumi, A. Hassan, Comparison of polylactic Acid/Kenaf and polylactic Acid/Rise husk composites: The influence of the natural fibers on the mechanical, thermal and biodegradability properties, J. Polym. Environ. 18 (2010) 422-429. https://doi.org/10.1007/s10924-010-0185-0.

[42] M. Ghorbani Chaboki, J. Mohammadi-Rovshandeh, F. Hemmati, Poly(lactic acid)/thermoplasticized rice straw biocomposites: effects of benzylated lignocellulosic filler and nanoclay, Iran. Polym. J. (English Ed. 28 (2019) 777-788. https://doi.org/10.1007/s13726-019-00743-1.

[43] A. Zandi, A. Zanganeh, F. Hemmati, J. Mohammadi-Roshandeh, Thermal and biodegradation properties of poly(lactic acid)/rice straw composites: effects of modified pulping products, Iran. Polym. J. (English Ed. 28 (2019) 403-415. https://doi.org/10.1007/s13726-019-00709-3.

[44] A.P. Morales, A. Güemes, A. Fernandez-Lopez, V.C. Valero, S. de La Rosa Llano, Bamboo-polylactic acid (PLA) composite material for structural applications, Materials (Basel). 10 (2017) 1286. https://doi.org/10.3390/ma10111286.

[45] D. Li, Y. Jiang, S. Lv, X. Liu, J. Gu, Q. Chen, Y. Zhang, Preparation of plasticized poly (lactic acid) and its influence on the properties of composite materials, PLoS One. 13 (2018) e0193520. https://doi.org/10.1371/journal.pone.0193520.

[46] M. Soleimani, L.G. Tabil, I. Oguocha, J. Fung, Interactive Influence of Biofiber Composition and Elastomer on Physico-Mechanical Properties of PLA Green Composites, J. Polym. Environ. 26 (2018) 532-542. https://doi.org/10.1007/s10924-017-0967-8.

[47] A. Grząbka-Zasadzińska, M. Odalanowska, S. Borysiak, Thermal and mechanical properties of biodegradable composites with nanometric cellulose, J. Therm. Anal. Calorim. 138 (2019) 4407-4416. https://doi.org/10.1007/s10973-019-09023-9.

[48] M.M. Hassan, M.J. Le Guen, N. Tucker, K. Parker, Thermo-mechanical, morphological and water absorption properties of thermoplastic starch/cellulose composite foams reinforced with PLA, Cellulose. 26 (2019) 4463-4478. https://doi.org/10.1007/s10570-019-02393-1.

[49] X. Zhang, L. Chen, T. Mulholland, T.A. Osswald, Characterization of mechanical properties and fracture mode of PLA and copper/PLA composite part manufactured by fused deposition modeling, SN Appl. Sci. 1 (2019) 616. https://doi.org/10.1007/s42452-019-0639-5.

[50] P.O. Bussiere, S. Therias, J.L. Gardette, M. Murariu, P. Dubois, M. Baba, Effect of ZnO nanofillers treated with triethoxy caprylylsilane on the isothermal and non-isothermal crystallization of poly(lactic acid), Phys. Chem. Chem. Phys. 14 (2012) 12301-12308. https://doi.org/10.1039/c2cp41574g.

[51] M. Murariu, A. Doumbia, L. Bonnaud, A.L. Dechief, Y. Paint, M. Ferreira, C. Campagne, E. Devaux, 
P. Dubois, High-performance polylactide/ZnO nanocomposites designed for films and fibers with special end-use properties, Biomacromolecules. 12 (2011) 1762-1771. https://doi.org/10.1021/bm2001445.

[52] M.E. Hoque, Processing and Characterization of Cockle Shell Calcium Carbonate (CaCO3) Bioceramic for Potential Application in Bone Tissue Engineering, J. Mater. Sci. Eng. 02 (2013). https://doi.org/10.4172/2169-0022.1000132.

[53] J.Z. Liang, L. Zhou, C.Y. Tang, C.P. Tsui, Crystalline properties of poly(L-lactic acid) composites filled with nanometer calcium carbonate, Compos. Part B Eng. $45 \quad$ (2013) 1646-1650. https://doi.org/10.1016/j.compositesb.2012.09.086.

[54] Y.B. Nekhamanurak, P. Patanathabutr, N. Hongsriphan, Mechanical Properties of Hydrophilicity Modified CaCO3-Poly (Lactic Acid) Nanocomposite, Int. J. Appl. Phys. Math. (2012) 98-103. https://doi.org/10.7763/ijapm.2012.v2.62.

[55] N. Shi, J. Cai, Q. Dou, Crystallization, morphology and mechanical properties of PLA/PBAT/CaCO3 composites, in: Adv. Mater. Res., 2013: pp. https://doi.org/10.4028/www.scientific.net/AMR.602-604.768.

[56] W.M. Chiu, Y.A. Chang, H.Y. Kuo, M.H. Lin, H.C. Wen, A study of carbon nanotubes/biodegradable plastic polylactic acid composites, J. Appl. Polym. Sci. $108 \quad$ (2008) 3024-3030. https://doi.org/10.1002/app.27796.

[57] K. Fukushima, M. Murariu, G. Camino, P. Dubois, Effect of expanded graphite/layered-silicate clay on thermal, mechanical and fire retardant properties of poly(lactic acid), Polym. Degrad. Stab. 95 (2010) 1063-1076. https://doi.org/10.1016/j.polymdegradstab.2010.02.029.

[58] L. Suryanegara, A.N. Nakagaito, H. Yano, The effect of crystallization of PLA on the thermal and mechanical properties of microfibrillated cellulose-reinforced PLA composites, Compos. Sci. Technol. 69 (2009) 1187-1192. https://doi.org/10.1016/j.compscitech.2009.02.022.

[59] P. Tingaut, T. Zimmermann, F. Lopez-Suevos, Synthesis and characterization of bionanocomposites with tunable properties from poly(lactic acid) and acetylated microfibrillated cellulose, Biomacromolecules. 11 (2010) 454-464. https://doi.org/10.1021/bm901186u.

[60] I. Spiridon, K. Leluk, A.M. Resmerita, R.N. Darie, Evaluation of PLA-lignin bioplastics properties before and after accelerated weathering, Compos. Part B Eng. 69 (2015) 342-349. https://doi.org/10.1016/j.compositesb.2014.10.006.

[61] B.K. Chen, C.H. Shen, A.F. Chen, Preparation of ductile PLA materials by modification with trimethyl hexamethylene diisocyanate, Polym. Bull. 69 (2012) 313-322. https://doi.org/10.1007/s00289-0120730-1.

[62] R. Pantani, G. Gorrasi, G. Vigliotta, M. Murariu, P. Dubois, PLA-ZnO nanocomposite films: Water vapor barrier properties and specific end-use characteristics, Eur. Polym. J. 49 (2013) 3471-3482. https://doi.org/10.1016/j.eurpolymj.2013.08.005.

[63] R. Malinowski, K. Janczak, P. Rytlewski, A. Raszkowska-Kaczor, K. Moraczewski, T. Zuk, Influence of glass microspheres on selected properties of polylactide composites, Compos. Part B Eng. 76 (2015) 13-19. https://doi.org/10.1016/j.compositesb.2015.02.013.

[64] Y. Li, C. Chen, J. Li, X.S. Sun, Synthesis and characterization of bionanocomposites of poly(lactic acid) and TiO2 nanowires by in situ polymerization, Polymer (Guildf). 52 (2011) 2367-2375. https://doi.org/10.1016/j.polymer.2011.03.050.

[65] Y.B. Luo, W. Da Li, X.L. Wang, D.Y. Xu, Y.Z. Wang, Preparation and properties of nanocomposites based on poly(lactic acid) and functionalized TiO2, Acta Mater. 57 (2009) 3182-3191. https://doi.org/10.1016/j.actamat.2009.03.022.

[66] M. Vallet-Regi, S. Granado, D. Arcos, M. Gordo, M. V. Cabanas, C. V. Ragel, A.J. Salinas, A.L. Doadrio, J. San Roman, Preparation, characterization, andin vitro release of Ibuprofen from Al2O3/PLA/PMMA composites, J. Biomed. Mater. Res. 39 (1998) 423-428. https://doi.org/10.1002/(SICI)10974636(19980305)39:3<423::AID-JBM11>3.0.CO;2-B.

[67] M. Sajjadi, M. Nasrollahzadeh, S. Mohammad Sajadi, Green synthesis of Ag/Fe3O4 nanocomposite using Euphorbia peplus Linn leaf extract and evaluation of its catalytic activity, J. Colloid Interface Sci. 497 (2017) 1-13. https://doi.org/10.1016/j.jcis.2017.02.037.

[68] M. Shabanian, M. Khoobi, F. Hemati, H.A. Khonakdar, S. esmaeil S. Ebrahimi, U. Wagenknecht, A. Shafiee, New PLA/PEI-functionalized Fe3O4 nanocomposite: Preparation and characterization, J. Ind. Eng. Chem. 24 (2015) 211-218. https://doi.org/10.1016/j.jiec.2014.09.032.

[69] M.Y. Razzaq, M. Behl, A. Lendlein, Magnetic memory effect of nanocomposites, Adv. Funct. Mater. 22 (2012) 184-191. https://doi.org/10.1002/adfm.201101590.

[70] S. Taccola, A. Desii, V. Pensabene, T. Fujie, A. Saito, S. Takeoka, P. Dario, A. Menciassi, V. Mattoli, Free- 
standing poly(l-lactic acid) nanofilms loaded with superparamagnetic nanoparticles, Langmuir. 27 (2011) 5589-5595. https://doi.org/10.1021/la2004134.

[71] S. Vacaras, M. Baciut, O. Lucaciu, C. Dinu, G. Baciut, L. Crisan, M. Hedesiu, B. Crisan, F. Onisor, G. Armencea, I. Mitre, I. Barbur, W. Kretschmer, S. Bran, Understanding the basis of medical use of polylactide-based resorbable polymers and composites-a review of the clinical and metabolic impact, Drug Metab. Rev. 51 (2019) 570-588. https://doi.org/10.1080/03602532.2019.1642911.

[72] S.M. Davachi, B. Kaffashi, Polylactic Acid in Medicine, Polym. - Plast. Technol. Eng. 54 (2015) 944-967. https://doi.org/10.1080/03602559.2014.979507.

[73] Z. Sheikh, S. Najeeb, Z. Khurshid, V. Verma, H. Rashid, M. Glogauer, Biodegradable materials for bone repair and tissue engineering applications, Materials (Basel). 8 (2015) 5744-5794. https://doi.org/10.3390/ma8095273.

[74] J.C. Bogaert, P. Coszach, Poly(lactic acids): A potential solution to plastic waste dilemma, in: Macromol. Symp., 2000: pp. 287-303. https://doi.org/10.1002/1521-3900(200003)153:1<287::AIDMASY287>3.0.CO;2-E.

[75] E.T.H. Vink, K.R. Rábago, D.A. Glassner, P.R. G ruber, Applications of life cycle assessment to NatureWorks ${ }^{\mathrm{TM}}$ polylactide (PLA) production, Polym. Degrad. Stab. 80 (2003) 403-419. https://doi.org/10.1016/S0141-3910(02)00372-5.

[76] S. Chiarakorn, C.K. Permpoonwiwat, P. Nanthachatchavankul, Financial and economic viability of bioplastic production in Thailand, 2014.

[77] Tides Center/Environmental Health Strategy Center; Maine Initiaties; Jim Lunt \& Associates LLC, The Business Case for Commercial Production of Bioplastics in Maine: A preliminary report, 2010.

[78] A. Manandhar, A. Shah, Techno-economic analysis of bio-based lactic acid production utilizing corn grain as feedstock, Processes. 8 (2020) 199. https://doi.org/10.3390/pr8020199.

[79] S. Sanaei, P.R. Stuart, Systematic assessment of triticale-based biorefinery strategies: techno-economic analysis to identify investment opportunities, Biofuels, Bioprod. Biorefining. 12 (2018) S46-S59. https://doi.org/10.1002/bbb.1499.

[80] E.T.H. Vink, D.A. Glassner, J.J. Kolstad, R.J. Wooley, R.P. O'Connor, The eco-profiles for current and nearfuture NatureWorks ${ }^{\circledR}$ polylactide (PLA) production, Ind. Biotechnol. 3 (2007) 58-81. https://doi.org/10.1089/ind.2007.3.058. 